\title{
Pelaksanaan Pengawasan Inspektorat Daerah pada Organisasi Perangkat Daerah Kabupaten Batang Hari
}

\author{
Fauziah $^{1 *}$, Yulia Istia Ningsih ${ }^{2}$, Sumantri $^{3}$ \\ ${ }^{1,2,3}$ Sekolah Tinggi Ilmu Ekonomi Graha Karya, Muara Bulian \\ "Correspondence email: fauziahh.stiegk@gmail.com
}

\begin{abstract}
The regional inspectorate functions as the internal auditor of the government which has the task of carrying out regional government general oversight activities and other tasks assigned by the regional head. In order to prevent the occurrence of irregularities and abuse of authority in the administration of government, in each government institution a government internal supervision institution is formed which specifically carries out the supervisory function. Government internal supervision institutions are institutions that are formed and internally are part of the government system that has the main tasks and functions in the field of supervision. The analytical method used in this research is descriptive qualitative method. This type of research used aims to obtain an overview and understanding and also explain how the supervision carried out by the Batang Hari Regional Inspectorate in the Batang Hari Regional Organization by basing on the results of observations, interviews, documentation, and literature studies. Based on the results of research conducted by the author of the Implementation of Supervision of Regional Inspectorate in the Regional Organization of the Batang Hari Regency, in general it has been implemented well, effectively and in accordance with the SOP, but there are still shortcomings, one of which is the timeliness in the issuance of the Audit Report.
\end{abstract}

Keywords : Executive supervision, Regional Inspectorate

\section{Pendahuluan}

Inspektorat daerah berfungsi sebagai auditor internal pemerintah yang mempunyai tugas menyelenggarakan kegiatan pengawasan umum pemerintah daerah dan tugas lain yang diberikan kepala daerah. Lembaga ini merupakan suatu lembaga pengawas di lingkungan pemerintah daerah. Inspektorat daerah memainkan peran yang sangat penting untuk kemajuan dan keberhasilan pemerintah daerah dan perangkat daerah dalam menyelenggarakan pemerintahan. Posisi APIP ditempatkan secara tepat sehingga bebas dari intervensi, dan memperoleh dukungan yang memadai dari Pimpinan Kementerian/ Lembaga/Pemerintah Daerah sehingga dapat bekerja sama dengan auditi dan melaksanakan pekerjaan dengan leluasa. Prinsip obyektifitas mensyaratkan agar auditor melaksanakan penugasan dengan jujur dan tidak mengompromikan kualitas. Untuk mengoptimalkan kinerja tata kelola pemerintah yang baik khususnya dalam pelaksanaan pembinaan, diperlukan pula pengawasan yang baik. Bertolak dari latar belakang yang telah dipaparkan sebelumnya saya tertarik untuk meneliti tentang pengawasan ini.

\section{Tinjauan Pustaka \\ Konsep Pengawasan}

Menurut Schemerhorn pengawasan adalah proses dalam menetapkan ukuran kinerja dan pengambilan tindakan yang dapat mendukung pencapaian hasil yang diharapkan sesuai dengan kinerja yang telah ditetapkan tersebut. Controlling is the process of measuring performance and taking action to ensure desired result. Pengawasan adalah proses untuk memastikan bahwa segala aktifitas yang terlaksana sesuai dengan apa yang telah direncanakan. The process of ensuring that actual activities conform the planned activities"

\section{Fungsi dan Tujuan Pengawasan}

Menurut Situmorang dan Juring (1994) maksud pengawasan adalah untuk: (a) mengetahui jalannya pekerjaan apakah lancar atau tidak; (b) memperbaiki kesalahan-kesalahan yang dibuat oleh pegawai dan mengadakan pencegahan agar tidak terulang kembali kesalahan-kesalahan yang sama atau timbulnya kesalahan baru; (c) mengetahui apakah penggunaan budget yang telah ditetapkan dalam rencana terarah kepada sasarannya dan sesuai dengan yang telah direncanakan; (d) mengetahui pelaksanaan kerja sesuai dengan program (fase tingkat pelaksanaan) seperti yang telah ditentukan dalam planning atau tidak; dan (e) mengetahui hasil pekerjaan dibandingkan dengan yang telah ditetapkan dalam planning, yaitu standar.

Lebih lanjut mengenai tujuan pengawasan, adalah (1) membandingkan antara pelaksanaan dengan rencana serta instruksi-instruksi yang telah dibuat; (2) untuk mengetahui ada tidaknya kesulitan-kesulitan, kelemahan-kelemahan atau kegagalan-kegagalan serta efisinsi dan efektifitas kerja; dan (3) untuk mencari jalan keluar apabila ada kesulitan, kelemahan dan kegagalan, atau dengan kata lain disebut tindakan korektif. 


\section{Macam-macam Teknik Pengawasan}

Menurut pendapat Koontz, et. al, tentang teknik pengawasan, terdapat dua cara untuk memastikan pegawai merubah tindakan/sikapnya yang telah mereka lakukan dalam bekerja, yaitu dengan dilakukannya pengawasan lansung (direct control) dan pengawasan tidak lansung (indirect control). Pengawasan lansung diartikan sebagai teknik pengawasan yang dirancang untuk mengidentifikasi dan memperbaiki penyimpangan rencana. Tujuannya adalah agar penyimpangan-penyimpangan terhadap rencana yang terjadi dapat diidentifikasi dan diperbaiki. Menurut Koontz, et. al, pengawasan lansung sangat mungkin dilakukan apabila tingkat kualitas para pimpinan dan bawahannya rendah. Sementara pengawasan tidak lansung dapat diartikan sebagai teknik pengawasan yang dilakukan dengan menguji, meneliti laporan-laporan pelaksanaan kerja.

\section{Fungsi-fungsi pengawasan}

Fungsi pengawasan adalah identifikasi berbagai faktor yang menghambat sebuah kegiatan, dan juga pengambilan tindakan koreksi yang diperlukan agar tujuan organisasi dapat tercapai. Sebagai kesimpulan, fungsi pengawasan diperlukan untuk memastikan apa yang telah direncanakan dan dikoordinasikan berjalan sebagaimana mestinya ataukah tidak.

\section{Tindak Lanjut Pengawasan}

Sesuai dengan instruksi Presiden Nomor 15 Tahun 1983, tindak lanjut pengawasan terdiri dari :

1. Tindakan administratif sesuai dengan ketentuan perundang-undangan di bidang kepegawaian termasuk penerapan hukum disiplin yang dimaksudkan didalam pemerintahan Nomor 53 Tahun 2010 tentang pengaturan didiplin pegawai negeri sipil.

2. Tindakan tuntutan atau gugatan perdata yaitu (a) tuntutan ganti rugi atau penyetoran kembali; (b) tuntutan perbendaharaan; dan (c) tuntutan pengenaan denda, ganti rugi, dll.

3. Tindakan pengaduan tindak pidana dengan menyerahkan perkaranya kepada kepolisian Negara Republik Indonesia dalam hal terdapat indikasi pidana umum, atau kepala Kejaksaan Republik Indonesia dalam hal terdapat indikasi tindakan pidana khusus.

4. Tindakan penyempurnaan aparatur pemerintahan dibidang kelembagaan, kepegawaian dan ketatalaksanaan.

\section{Tahapan-tahapan pengawasan}

1. Tahap Penetapan Standar, tujuannya adalah sebagai sasaran, kuota dan target pelaksanaan kegiatan yang digunakan sebagai patokan dalam pengambilan keputusan. Bentuk standar yang umum yaitu : standar fisik, standar moneter, dan standar waktu

2. Tahap penentuan Pengukuran Pelaksanaan Kegiatan, digunakan sebagai dasar atas pelaksanaan kegiatan yang dilakukan secara tepat.

3. Tahap Pengukuran Pelaksanaan Kegiatan, beberapa proses yang berulang-ulang dan kontinue yang berupa atas pengamatan laporan, metode, pengujian, dan sampel.

4. Tahap Pembandingan Pelaksanaan dengan Standar dan Analisa Penyimpangan

5. Tahap Pengambilan Tindakan Koreksi, bila diketahui dalam pelaksanaannya terjadi penyimpangan, dimana perlu adanya perbaikan pelaksanaan.

\section{Pengawasan yang Efektif}

Pengawasan yang efektif menurut Sarwoto yaitu :

1. Ada unsur keakuratan, dimana data harus dapat dijadikan pedoman dan valid.

2. Tepat waktu, yaitu dikumpulkan, disampaikan, dan dievaluasikan secara tepat dan cepat dimana kegiatan perbaikan perlu dilaksanakan.

3. Objektif dan menyeluruh, dalam arti mudah dipahami

4. Terpusat dengan memutuskan pada bidang-bidang penyimpangan yang paling sering terjadi.

5. Realistis secara ekonomis, dimana biaya sistem pengawasan harus lebih rendah atau sama dengan kegunaan yang didapat.

6. Realistis secara organisasional, yaitu cocok dengan kenyataan yang ada diorganisasi.

7. Terkoordinasi dengan aliran kerja, karena dapat menimbulkan sukses atau gagal serta harus sampai pada karyawan yang memerlukannya.

8. Fleksibel, harus dapat menyesuaikan dengan situasi yang dihadapi, sehingga tidak harus buat sitem baru bila terjadi perubahan kondisi.

9. Sebagai petunjuk dan operasional, dimana harus dapat menunjukan deviasi standar sehingga dapat menentukan koreksi yang diambil. 
10. Diterima para anggota organisasi, maupun mengarahkan pelaksanaan kerja anggota organisasi dengan mendorong peranan otonomi, tanggung jawab dan prestasi.

\section{Konsep Inspektorat}

Pengawasan atas penyelenggaraan pemerintah daerah merupakan amanat dari ketentuan Pasal 218 Undangundang Nomor 32 Tahun 2004 tentang Pemerintahan Daerah, yang menyatakan :

1. Pengawasan atas penyelenggaraan pemerintahan daerah dilaksanakan oleh Pemerintah meliputi (a) pengawasan atas pelaksanaan urusan pemerintahan di daerah; dan (b) pengawasan terhadap peraturan daerah dan peraturan kepala daerah

2. Pengawasan sebagaiman dimaksud pada poin 1 huruf a dilaksanan oleh Aparat Pengawas Intern Pemerintah (APIP) sesuai peraturan perundang-undangan.

\section{Hasil}

\section{Pelaksanaan Pengawasan Inspektorat Daerah Pada Organisasi Perangkat Daerah Kabupaten Batang Hari}

Pengawasan adalah untuk meningkatkan pendayagunaan aparatur negara dalam melaksanakan tugas-tugas umum pemerintahan dan pembangunan menuju terwujudnya pemerintahan yang baik dan bersih (good government and clean government). Kesalahan harus ditebus dengan sanksi/hukuman, dan bila memenuhi unsur tindak pidana harus diproses oleh aparat penegak hukum, sehingga membuat efek jera bagi pelaku dan orang lain berpikir seribu kali untuk melakukan hal yang sama, sehingga praktek Korupsi, Kolusi dan Nepotisme (KKN) menjadi berkurang dan akhirnya hilang. Untuk menciptakan pengawasan yang baik Inspektorat Kabupaten Batang Hari menekankan pada perencanaan program pengawasan, pelaksanaan pengawasan, penyusunan laporan hasil pengawasan, serta pertanggungjawaban hasil pengawasan.

\section{Perencanaan Program Pengawasan Inspektorat Daerah Kabupaten Batang Hari}

Inspektorat Daerah Kabupaten Batang Hari tentu memiliki sebuah perencanaan untuk bisa mengawasi jalannya pemerintahan yang ada di Kabupaten Batang Hari. Perencanaan yang dibuat tergambar dalam wawancara dengan Kepala Sub Bagian Perencanaan, yang menyatakan: sebelum melakukan pemeriksaan, Inspektorat Daerah Kabupaten Batang Hari terlebih dahulu membuat perencanaan program pengawasan dalam bentuk PKPT (Program Kerja Pengawasan Tahunan) (Wawancara tanggal 01 Agustus 2019). Penyusunan PKPT (Program Kerja Pengawasan Tahunan) merupakan wujud dari pengaplikasian fungsi Inspektorat Daerah yang tercermin dalam peraturan Bupati Nomor 28 Tahun 2018 Paragraf 1 Pasal 10 tentang Kedudukan, Tugas, dan Fungsi Sub Bagian Perencanaan yang menjadi tuntutan untuk dilaksanakan setiap tahunnya sebelum tahun anggaran dimulai. Namun sebelum PKPT (Program Kerja Pengawasan Tahunan) itu disetujui ditingkat Provinsi, Inspektorat Kabupaten Batang Hari terlebih dahulu membuat RPKPT (Rancangan Program Kerja Pengawasan Tahunan). Hal ini sesuai dengan penjelasan Sekretaris Inspektorat, yang mengatakan: sebelum diusulkan dalam rapat koordinasi pengawasan di Inspektorat Provinsi yang dihadiri oleh seluruh Inspektorat Kabupaten/Kota se Provinsi Jambi, terlebih dahulu kami membuat Rancangan Program Kerja Pengawasan Tahunan atau RPKPT (wawancara tanggal 01 Agustus 2019). Di dalam pembuatan suatu perencanaan dibutuhkan sebuah pengalaman dan kompetensi. Kemampuan menganalisis kebutuhan dan pengawasan dalam pembuatan perencanaan itu sendiri.

Berdasarkan wawancara yang dilakukan dengan Inspektur Inspektorat Daerah Kabupaten Batang Hari, yang menyatakan pembuatan RPKPT (Rancangan Program Kerja Pengawasan Tahunan) dilakukan oleh para pejabat Inspektorat yang memiliki cukup pengalaman dan berkompeten (wawancara tanggal 02 Agustus 2019). Banyaknya pengalaman yang telah didapatkan dan kompetensi yang dimiliki oleh para pejabat Inspektorat dalam membuat perencanaan membuat para pejabat tersebut tidak membutuhkan waktu lama dalam membuat RPKPT. Hal ini sesuai dengan wawancara yang dilakukan kepada Inspektur Pembantu I, yang mengatakan pembuatan Rancangan Program Kerja Pengawasan Tahunan (RPKPT) itu kami buat paling lama 3 (tiga) hari (wawancara tanggal 02 Agustus 2019).

Hal ini menyerupai dengan apa yang dikatakan oleh Inspektur Pembantu II, yang mengatakan bahwa Alhamdulillah RPKPT yang setiap tahun kita buat selalu selesai dalam 2 (dua) hari (wawancara tanggal 02 Agustus 2019). Setelah mengajukan Rancangan Program Kerja Pengawasan Tahunan (RPKPT) kepada Inspektorat Provinsi dan kemudian telah disetujui oleh Bupati Batang Hari, maka ditetapkanlah Program Pengawasan Tahunan (PKPT) sebagai pedoman pelaksanaan pemeriksaan. Didalam pembuatan Program Kerja Pengawasan Tahunan (PKPT) tentu tidak terlepas dari target yang akan dicapai oleh Inspektorat Daerah Kabupaten Batang Hari dalam menunjang Visi dan Misinya. Hal ini tergambar dalam tergambar dalam RENJA Inspektorat Kabupaten Batang Hari Tahun 2018.

Sasaran Pertama berupa Meningkatnya Kualitas Pengawasan Intern Pemerintah. Dicapai melalui program peningkatan sistem Pengawasan Internal dan Pengendalian Pelaksanaan Kebijakan KDH, Indikator sasaran berupa :

a. Menurunnya pengaduan masyarakat atas kerugian Daerah Pencapaian sasaran dilakukan melalui kegiatan: Kegiatan Pemeriksaan Kasus Pengaduan Masyarakat Pada kegiatan ini melaksanakan pemeriksaan terhadap seluruh 
pengaduan masyarakat yang diterima oleh Inspektorat Daerah. Namun yang menjadi Indikator adalah pengaduan masyarakat yang mengandung unsur kerugian daerah. Kegiatan Saber Pungli dengan target tingkat capaian 100\% Sedangkan Perencanaan kasus pengaduan masyarakat yang diterima oleh Inspektorat Daerah Kabupaten Batang Hari selama 5 tahun dari Tahun 2017 s/d 2021. Menurunnya Temuan BPK atas Laporan Keuangan Pencapaian Indikator sasaran pada Tahun 2018. Kegiatan Pelaksanaan pembinaan dan pengawasan internal secara berkala dengan tingkat capaian 100\% Kegiatan yang dilaksanakan dalam rangka mencapai indikator sasaran tersebut adalah dengan melakukan pengawasan reguler kesetiap SKPD, Desa dan Dana BOS.

b. Meningkatnya Tindak Lanjut atas Temuan BPK dan APIP Pencapaian Indikator sasaran pada Tahun 2018 dilakukan dengan kegiatan antara lain: kegiatan fasilitasi dan monitoring percepatan penyelesaian Tindak. Jumlah Rekomendasi atas temuan pemeriksaan aparat pengawasan fungsional pemerintah terdiri dari pemeriksaan Inspektorat Kabupaten Batang Hari, Inspektorat Provinsi Jambi dan BPK Perwakilan Provinsi Jambi sebanyak $83 \%$.

c. Terwujudnya implementasi SPIP yang memadai Pencapaian indikator sasaran dilaksanakan dengan kegiatan : Kegiatan Sosialisasi dan Pembinaan SPIP dengan tingkat capaian SPIP Pemerintah Daerah level 2. Sedangkan Perencanaan pembinaan SPIP Organisasi Perangkat Daerah Pemerintah Kabupaten Batang Hari selama 5 tahun dari tahun 2017 s/d 2021 Nilai Evaluasi Sakip Minimal B. Pencapaian Indikator sasaran dilakukan dengan kegiatan antara lain: Kegiatan Evaluasi dan Reviu Perencanaan, akuntabilitas dan Pelaporan. Dokumen yang dilakukan Evaluasi dan Reviu sebagai berikut : Laporan Kinerja SKPD, Laporan Keuangan Pemerintah Daerah, Laporan Kinerja Pemerintah Daerah, Rencana Kegiatan Pemerintah Daerah, Reviu Pengadaan Barang dan Jasa, dan Reviu RKA

d. Terbentuknya Zona Integritas, pencapaian atas indikator sasaran terbentuknya Zona Integritas melalui kegiatan Fasilitasi Pembangunan Zona Integritas. Pada tahun 2018 Indikator kegiatan adalah target pembangunan Zona Integritas OPD ditargetkan 2 OPD.

e. Terlaksananya Kegiatan OPD dan Desa, Pencapaian atas indikator sasaran terlaksananya kegiatan OPD dan Desa melalui kegiatan Fasilitasi Percepatan Penyerapan Anggaran. Pada tahun 2018 ditargetkan 100\% kegiatan OPD dan Desa yang disampaikan kepada Kejaksaan Negeri Muara Bulian dapat dilakukan pendampingan.

Sasaran kedua berupa Meningkatnya Kapalitas APIP, Memiliki indikator Nilai Kapabilitas APIP dicapai melalui program Peningkatan Profesinalisme Tenaga Pemeriksa dan Aparatur Pengawasan. Pencapaian sasaran dilakukan melalui kegiatan berupa :Pendidikan dan Pelatihan Teknis dan Fungsional APIP Pengiriman APIP mengikuti kegiatankegiatan Pendidikan dan Pelatihan teknis Substansi ditargetkan pada 35 orang. Pengiriman Diklat Teknis Auditor 5 orang. Kegiatan Pelatihan Kantor Sendiri Meningkatnya wawasan Auditor khusunya APIP pada umumnya dengan melaksanakan study komparatif APIP daerah yang kapabilitas APIP level diatas Inspektorat Daerah Kabupaten Batang Hari.

\section{Tahapan Pelaksanaan Pengawasan Inspektorat Pada Organisasi Perangkat Daerah Kabupaten Batang Hari}

Sesuai dengan standar audit Aparat Internal Pemerinta (APIP) sebagaimana diatur dalam Peraturan Menteri Negara Pendayagunaan Aparatur Negara no. PER/05/M.PAN/03/2008 tanggal 31 Maret 2008 pada standar umum telah ditetapkan tentang standar keahlian bahwa auditor harus mempunyai pengetahuan, ketrampilan, dan kompetensi lainnya yang diperlukan untuk melaksanakan tanggung jawabnya, selanjutnya pada standar pendidikan auditor, telah ditetapkan bahwa auditor APIP harus mempunyai tingkat pendidikan formal minimal S1 atau yang setara. Tahapan-tahapan pengawasan yang dilakukan oleh Inspektorat Daerah Kabupaten Batang Hari terperinci berdasarkan hasil wawancara dengan Kepala Sub Bagian Perencanaan, yakni sebagai berikut :

1. Pembentukan Tim

a. Didasarkan pada :

1) Surat perintah kepala Inspektorat atas nama Bupati yang berisikan susunan tim, auditan, ruang lingkup, audit, waktu secara kewajiban yang dibebankan kepada tim.

2) Surat perintah untuk penanganan yang bersifat khusus yang berisikan susunan tim, auditan, ruang lingkup, audit, waktu secara kewajiban yang dibebankan kepada tim.

b. Susunan, Wewenang dan Tanggung jawab Tim

1) Menetapkan personal tim

2) Mendatangani surat perintah tim atas nama Bupati

3) Melaksanakan review pelaksanaan audit

4) Menerima ekspose hasil audit dari koordinasi dan ketua tim

5) Menandatangani LHP (Laporan Hasil Pemeriksaan)

6) Memaraf surat Bupati

7) Mempertanggungjawabkan seluruh kegiatan audit

2. Pemberitahuan Pada Auditan 
Pemberitahuan pada auditan dilakukan 2 (dua) minggu sebelum pelaksanaan pengawasan. Pemberitahuan ini menyangkut kapan pemeriksaan akan dilaksanakan, lamanya pemeriksaan dan nama pemeriksa yang akan ditugaskan. Dalam pemberitahuan ini harus dilampirkan daftar permintaan informasi dan data yang akan diperlukan untuk survey pendahuluan.

3. Survey

Survey sebelum dilakukan pemeriksaan langkah awal yang dilakukan oleh inspektorat adalah melakukan survey program kerja dari Satuan Kerja Perangkat Daerah (SKPD) Kabupaten Batang Hari kemudian dijadikan objek atau sasaran pemeriksaan yang dilakukan oleh tim yang mendapatkan mandat untuk menjalankan pemeriksaan. Langkah ini dilakukan dengan jangka waktu satu minggu. Beliau juga menjelaskan bahwa dilakukan survey lapangan sebagai langkah pertama dalam proses pemeriksaan perlu dilakukan pengumpulan data yang relevan dengan kegiatan objek yang akan diperiksa sebagai dasar dalam penyusunan program kerja pemeriksaan (PKP). Dan pada saat kami melakukan survey kami membutuhkan waktu satu minggu dalam pengambilan data pada setiap SKPD yang akan diperiksa" (wawancara tanggal 05 Agustus 2019). Berdasarkan buku Petunjuk Operasional Pemeriksaan (POP) reguler Inspektorat Daerah Kabupaten Batang Hari tahun 2018, data yang perlu dikumpulkan pada saat survey pendahuluan meliputi :

1) Data permanen seperti peraturan-peraturan, struktur organisasi, uraian tugas, prosedur, kebijaksanaan dan lainlain.

2) Data yang tidak permanen antara lain data keuangan, kepegawaian, perlengkapan, dan lain-lain.

3) Data yang menyangkut tentang aktifitas objek yang akan diperiksa:

a. Tujuan penelaahan terhadap pengumpulan data permanen.

b. Tujuan penelaahan terhadap data tidak permanen.

c. Tujuan penelaahan terhadap aktifitas objek yang akan diperiksa yaitu mendapatkan gambaran mengenai ruang lingkup aktivitas dari objek yang akan diperiksa, laporan hasil pemeriksaan aparat pengawasan fungsional lainnya dan informasi dari pihak yang mempunyai hubungan objek yang diperiksa. Hal serupa diungkapkan Inspektur Pembantu I yang mengatakan bahwa Waktu yang diperlukan dalam melakukan survey oleh tim pemeriksa selama satu minggu. Dalam jangka waktu tersebut tim pemeriksa melakukan pengambilan data yang mereka butuhkan sebagai acuan pada saat pemeriksaan ingin dilakukan" (Wawancara tanggal 05 Agustus 2019).

\section{Program Kerja Pemeriksaan}

Program Kerja Pemeriksaan (PKP) dengan kepala perangkat daerah guna menjelaskan tentang langkah-langkah yang akan ditempuh setelah dilakukannya survey. PKP disusun oleh anggota tim pemeriksa dan disetujui oleh ketua tim.. Berdasarkan POP Reguler Inspektorat Daerah Kabupaten Batang Hari, PKP harus berfungsi sbb :

a. Rencana yang sistematis

b. Landasan pemberian tugas dari penanggung jawab pemeriksa kepada kepala bidang

c. Alat pembanding bagi kepala bidang antara lain pelaksanaan kegiatan dengan rencana-rencana yang ditetapkan

d. Alat pembantu dan melatih para kepala bidang dan penanggungjawab pemeriksa tentang urutan langkah yang harus dilaksanakan dalam pemeriksaan.

Susunan dari isi PKP

a. Informsi instansi yang diperiksa, sifat, dan periode yang diperiksa.

b. Tujuan dan ruang lingkup.

c. Sasaran pemeriksaan.

d. Pola laporan yang dikehendaki dapat berupa BAB atau surat.

e. Instruksi-instruksi khusus.

Langkah selanjutnya yaitu dalam wawancara dengan beliau mengungkapkan bahwa setelah dilakukannya survey dan penyusunan PKP maka dilakukan pengujian terhadap pengendalian manajemen yang meliputi organisasi seperti organisasi, kebijakan, prosedur, personalia, perencanaan, akuntansi, pelaporan, dan pengawasan intern pada perangkat daerah yang ingin diperiksa" Hal yang sama persis diutarakan oleh Sekretaris Inspektorat tanggal 05 Agustus 2019.

\section{Kertas Kerja Pemeriksaan}

Ketua tim wajib melengkapi hasil pemeriksaan dengan surat temuan, dan kertas kerja pemeriksaan serta melakukan pembahasan tentang hasil-hasil pemeriksaan dengan kepala perangkat daerah. Daftar temuan disusun berdasarkan urutan-urutan. KKP adalah catatan dan data yang dikumpulkan secara sistematis oleh kepala bidang/ ketua tim selama melakukan tugas pemeriksaan, kertas kerja harus mencerminkan langkah-langkah pemeriksaan yang ditempuh penguji. Berdasarkan POP Reguler 2019, PKP yang dituangkan dalam KKP isi daftar temuan memuat hal-hal 
sebagai berikut : Kondisi, Kriteria, Penyebab terjadinya penyimpangan, Akibat penyimpangan, Komentar Pejabat, dan Rekomendasi

Didalam melakukan pengawasan yang dilakukan Inspektorat tentu tidak terlepas dari prosedur pengawasan yang digunakan. Seperti yang dikatakan oleh Inspektur bahwa Prosedur pengawasan yang dilakukan yaitu reguler dan pengawasan khusus. Pengawasan reguler yaitu pengawasan yang dilakukan secara komprehensif sesuai dengan PKPT (Program Kerja Pengawasan Tahunan), sedangkan pengawasan khusus yaitu pengawasan yang dilakukan atas perintah Bupati. Dan ada juga pengawasan secara monitoring yaitu pengawasan yang dilakukan dengan menindaklanjuti laporan hasil pemeriksaan" (wawancara tanggal 05 Agustus 2019).

Pengawasan yang dilakukan Inspektorat terhadap Organisasi Perangkat Daerah Kabupaten Batang Hari merupakan pelaksanaan program kerja pengawasan tahunan (PKPT) yang bersifat reguler yang telah dilaksanakan pada tahun 2019 seperti yang telah dijelaskan oleh selaku Inspektur Pembantu I yang sekaligus menjadi auditor dalam pelaksanaan PKPT di Organisasi Perangkat Daerah Kabupaten Batang Hari. Untuk pelaksanaan program kerja pengawasan tahunan terhadap Organisasi Perangkat Daerah Kabupaten Batang Hari telah kami laksanakan" (Wawancara pada tanggal 05 Agustus 2019).

Dalam Pelaksanaan pengawasan dalam hal ini pengambilan data (survey) terhadap Organisasi Perangkat Daerah Kabupaten Batang Hari dilaksanakan dengan baik, seperti yang telah dijelaskan oleh Ketua Tim Audit bahwa Pelaksanaan pengambilan data di OPD Alhamdulillah berjalan dengan cukup baik, namun masih ada kendala yang kami temukan diantaranya keterlambatan penyediaan dan perampungan data dari OPD, adanyan berkas yang tercecer, dan jumlah auditor yang sedikit juga membuat lamban pengambilan data" (Wawancara tanggal 05 Agustus 2019).

\section{Penyusunan dan Penyampaian Laporan Hasil Pengawasan}

Laporan Hasil Pemeriksaan (LHP) tersebut adalah sarana komunikasi yang resmi tetapi bersifat rahasia dan sangat penting bagi pemeriksa untuk menyampaikan informasi tentang temuan, kesimpulan, dan rekomendasi kepada auditan atau yang perlu mengetahui informasi tersebut. LHP dibuat berdasarkan kertas kerja pemeriksaan dan naskah hasil audit yang disusun selama melaksanakan audit agar informasi akurat dan objektif. Seperti yang dibahas oleh Sekretaris Inspektorat, yang mengatakan bahwa setelah pelaksanaan pengawasan selesai, kami selanjutnya membuat laporan hasil pemeriksaan (LHP) yang dilakukan oleh masing-masing tim yang telah dibentuk" (wawancara tanggal 05 Agustus 2019). Ketua tim wajib melakukan penyusunan LHP (Laporan Hasil Pemeriksaan). LHP merupakan sasaran komunikasi resmi untuk menyampaikan seluruh informasi dari objek yang diperiksa tentang sesuatu realisasi kegiatan termaksud didalamnya mengimformasikan temuan baik yang bersifat positif maupun yang bersifat negatif dilengkapi dengan rekomendasi. (Hasil wawancara dengan Inspektur).

Hal diatas juga dibahas dalam wawancara dengan Inspektur Pembantu II yang mengatakan sesuai dengan Petunjuk Operasional Pemeriksaan (POP), Laporan Hasil Pemeriksaan (LHP) harus disampaikan dalam bentuk tertulis pada berbagai pihak yang berkepentingan sebagai sarana komunikasi dari pelaksanaan pengawasan (Tanggal 05 Agustus 2019).

Berdasarkan pengamatan penulis dari informasi yang dijelaskan oleh informan dan didukung dengan fakta yang ada dilapangan. Penulis dapat mengatakan bahwa pelaksanaan pengawasan tahunan yang dilakukan oleh Inspektorat Kabupaten Batang Hari terhadap Organisasi Perangkat Daerah telah dilaksanakan dengan baik.

\section{Faktor-faktor yang Mempengaruhi Pengawasan Inspektorat Daerah Pada Organisasi Perangkat Daerah Kabupaten Batang Hari}

Di dalam melakukan aktifitasnya sebagai Pengawas Fungsional terhadap penyelenggaraan pemerintahan daerah Inspektorat Kabupaten Batang Hari tidak terlepas dari faktor-faktor yang mempengaruhi yaitu faktor internal yaitu jumlah aparat pengawas, dan faktor eksternal yaitu ketersediaan anggaran dan kelalaian objek pemeriksaan. Hal ini dapat dijelaskan sebagai berikut :

a. Faktor Internal

Dalam hubungannya dengan uraian diatas maka dari hasil wawancara dengan Sekretaris Inspektorat Daerah Kabupaten Batang Hari sebagai berikut :Pelaksanaan pengawasan terhadap penyelenggaraan pemerintahan dalam hal ini Organisasi Perangkat Daerah sangat ditunjang oleh jumlah aparatur dalam melakukan pengawasan" (Wawancara tanggal 05 Agustus 2019). Kurangnya tenaga pemeriksa menjadi faktor yang paling berpengaruh didalam melakukan pengawasan. Berdasarkan hasil wawancara dengan Kepala Sub Bagian Perencanaan, yang mengatakan bahwa :Inspektorat Daerah Kabupaten Batang Hari saat ini hanya memiliki 44 orang pegawai, Inspektorat Daerah Kabupaten Batang Hari memiliki 8 pejabat struktural dan 12 orang pejabat fungsional Auditor" (Tanggal 05 Agustus 2019).

b. Faktor Eksternal

Faktor eksternal yakni berupa ketersediaan anggaran yang diberikan serta adanya kelalaian yang dilakukan objek pemeriksaan. Seperti yang diungkapkan oleh Sekretaris Inspektorat Daerah Kabupaten Batang Hari yakni selain 
faktor Internal yang telah saya bahas tadi, faktor lainnya yaitu minimnya anggaran yang diberikan dalam melakukan pengawasan. (Wawancara tanggal 05 Agustus 2019)..Hal serupa juga dikatakan oleh Inspektur yang mengatakan bahwa Saat ini kami selalu terkendala dengan minimnya anggaran yang tersedia sehingga objek pemeriksaan terpaksa dikurangi terlebih lagi yang diperiksa adalah semua Organisasi Perangkat Daerah (Wawancara tanggal 05 Agustus 2019). Selain ketersediaan anggaran yang diberikan, faktor lain yang ditemukan seringkali dokumendokumen yang dibutuhkan pada saat pemeriksaan itu terlambat diberikan. Selain itu pejabat pemerintah yang diperiksa seringkali tidak sedang berada dilokasi saat aparat melakukan pemeriksaan. (Hasil wawancara dengan Inspektur Pembantu Wilayah IV tanggal 05 Agustus 2019). Menanggapi hal tersebut pihak Satuan Kerja Perangkat Daerah mengakui adanya keterlambatan data dikarenakan banyaknya kegiatan yang harus diselesaikan dalam waktu yang bersamaan.

\section{Simpulan}

1. Berdasarkan hasil penelitian yang dilakukan oleh Penulis terhadap Pelaksanaan Pengawasan Inspektorat Daerah pada Organisasi Perangkat Daerah Kabupaten Batang Hari, secara umum sudah terlaksana dengan baik, efektif dan sesuai SOP, tetapi juga masih terdapat kekurangan salah satunya adalah ketepatan waktu dalam penerbitan Laporan Hasil Pemeriksaan.

2. Beberapa faktor yang mempengaruhi Pelaksanaan Pengawasan diantaranya adalah Fakor Internal yaitu keterbatasan jumlah APIP jika dibandingkan dengan beban kerja yang ada saat ini, Faktor eksternal yaitu Anggaran yang diberikan tidak sesuai dengan jumlah kegiatan

\section{Daftar Pustaka}

Amins Achmad, 2012, Manajemen Kinerja Pemerintah Daerah, Laksbang Pressindo : Yogyakarta

Bintang Susmanto, 2009, Pengawasan Fungsional. Remaja Rosdakarya, Bandung

B.Uno Hamzah \& Latemenggo, 2012, Teori Kinerja dan Pengukurannya, Bumi Aksara, Gorontalo

Mulyadi, 2007, Sistem perencanaan dan pengendalian, edisi 7 buku 1, Penerbit Salemba 4 Jakarta. Jj

Peraturan Pemerintah Nomor 27 Tahun 2005 Tentang Pembinaan dan Pengawasan Atas Penyelenggaraan Pemerintah Daerah.

Reksohadiprodjo, Sukanto, 2008, Dasar-dasar Manajemen, edisi keenam, cetakan kelima, Penerbit: BPFE, Yogyakarta Suriansyah, 2014. Manajemen Pengawasan Pemerintahan Daerah. Pustaka Pelajar

Sarwoto, 2010, Dasar-dasar Organisasi dan Manajemen, cetakan keenam belas, Penerbit : Ghalia Indonesia, Jakarta

Siagian P. Sondang, 2008, Pengantar Manajemen, edisi pertama cetakan pertama, Penerbit : Bumi Aksara, Jakarta Siswandi dan Indra Imam, 2009, Aplikasi Manajemen Perusahaan, edisi kedua, Penerbit : Mitra Wicana Media, Jakarta

Terry, R, George dan Leslie W, Rue, 2010, Dasar-dasar Manajemen, edisi Bahasa Indonesia, cetakan ketiga belas, Penerbit : Bumi Aksara, Jakarta

Undang-Undang Nomor 23 Tahun 2014 Tentang Pemerintahan Daerah.

Undang-Undang Nomor 30 Tahun 2014 Tentang Administrasi Pemerintahan. 